\title{
Geological-Geomorphological and Paleontological Heritage in the Algarve (Portugal) Applied to Geotourism and Geoeducation
}

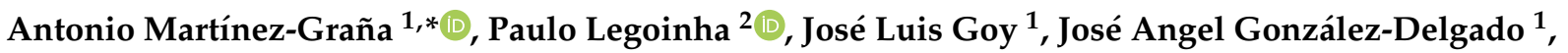 \\ Ildefonso Armenteros ${ }^{1}$, Cristino Dabrio ${ }^{3}$ and Caridad Zazo ${ }^{4}$ \\ 1 Department of Geology, Faculty of Sciences, University of Salamanca, 37008 Salamanca, Spain; \\ joselgoy@usal.es (J.L.G.); angel@usal.es (J.A.G.-D.); ilde@usal.es (I.A.) \\ 2 GeoBioTec, Department of Earth Sciences, NOVA School of Science and Technology, \\ Universidade NOVA de Lisboa, Caparica, 2829-516 Almada, Portugal; pal@fct.unl.pt \\ 3 Department of Stratigraphy, Faculty of Geology, Complutense University of Madrid, 28040 Madrid, Spain; \\ dabrio@geo.ucm.es \\ 4 Department of Geology, Museo Nacional de Ciencias Naturales, 28006 Madrid, Spain; carizazo@mncn.csic.es \\ * Correspondence: amgranna@usal.es; Tel.: +34-923294496
}

\section{check for} updates

Citation: Martínez-Graña, A.; Legoinha, P.; Goy, J.L.;

González-Delgado, J.A.; Armenteros,

I.; Dabrio, C.; Zazo, C.

Geological-Geomorphological and

Paleontological Heritage in the Algarve (Portugal) Applied to Geotourism and Geoeducation. Land 2021, 10, 918. https://doi.org/ 10.3390/land10090918

Academic Editor: Wojciech Zgłobicki

Received: 30 July 2021

Accepted: 27 August 2021

Published: 31 August 2021

Publisher's Note: MDPI stays neutral with regard to jurisdictional claims in published maps and institutional affiliations.

Copyright: (c) 2021 by the authors. Licensee MDPI, Basel, Switzerland. This article is an open access article distributed under the terms and conditions of the Creative Commons Attribution (CC BY) license (https:// creativecommons.org/licenses/by/ $4.0 /)$.

\begin{abstract}
A 3D virtual geological route on Digital Earth of the geological-geomorphological and paleontological heritage in the Algarve (Portugal) is presented, assessing the geological heritage of nine representative geosites. Eighteen quantitative parameters are used, weighing the scientific, didactic and cultural tourist interest of each site. A virtual route has been created in Google Earth, with overlaid georeferenced cartographies, as a field guide for students to participate and improve their learning. This free application allows loading thematic georeferenced information that has previously been evaluated by means of a series of parameters for identifying the importance and interest of a geosite (scientific, educational and/or tourist). The virtual route allows travelling from one geosite to another, interacting in real time from portable devices (e.g., smartphone and tablets), and thus making possible the ability to observe the relief and spatial geological distribution with representative images, as well as to access files with the description and analysis of each geosite. By using a field guide, each geosite is complemented with activities for carrying out and evaluating what has been learned; these resources allow a teaching-learning process where the student is an active part of the development and creation of content using new technologies that provide more entertaining and educational learning, teamwork and interaction with social networks. This itinerary allows the creation of attitudes and skills that involve geoconservation as an element for sustainable development.
\end{abstract}

Keywords: geoheritage; virtual itinerary; augmented reality; Algarve; Portugal

\section{Introduction}

The coast of the Algarve, at the South of Portugal (Figure 1) with a very mild climate, is a magnificent landscape with beautiful rocky and sandy beaches known worldwide and great touristic development. The rocks of the Neogene (dated from 19 to 3 million years) underwent processes of alteration, with development of very peculiar morphologies (among them those locally known as "algares") and a relief of exceptional beauty. In addition, the cliffs present a multitude of fossils, mainly of marine invertebrates such as mollusks, echinoderms, crustaceans, corals, bryozoans and rhodolits. Moreover, different types of carbonate and siliciclastic with their sedimentary structures are present, as well as representative geomorphological aspects such as karstifications such as karren, sinkholes (with or without deposit), tubes (pipes), caves and undercuts (notches). Furthermore, erosive marine terraces with deposit, alluvial and colluvial constitutute a remarkable example of geodiversity with high interest in scientific research, geoeducation and geoturistic activities. 


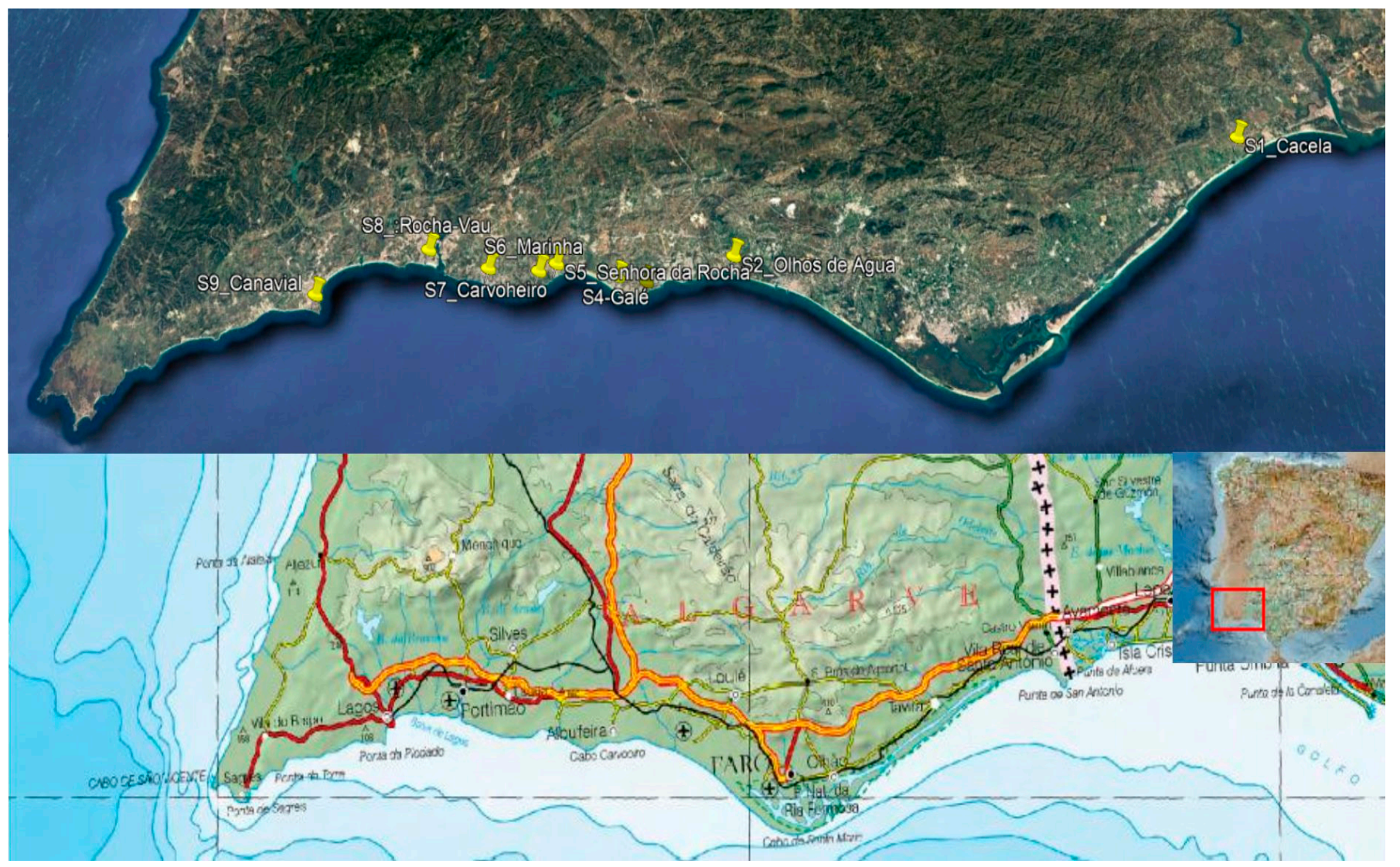

Figure 1. Satellite view and road map of the study area (selected geosites are indicated with yellow mark).

Among the geodiversity observable in a region, geological heritage consists of placesareas that stand out for their high scientific, educational and touristic-cultural interest. The high number of tourists per year and highly specialized tourism (geologists, geomorphologists and undergraduated/graduated students, etc.) achieved in the Algarve, due to its beauty and climate, led us to also consider geological aspects, such as the landscape, geomorphology and its rich macrofauna of fossil invertebrates, as very useful tools that enhance the value of the geological heritage in nine selected sites of the coastal strip of Neogene and Quaternary deposits of the Algarve region, including geological, geomorphological and paleontological data [1,2].

The teaching-learning processes in earth sciences involve, on the one hand, the theoretical contents in which the student understands and places in context the different concepts and areas of knowledge of geology (geomorphology, paleontology, tectonics, stratigraphy and so on) and, on the other hand, an analysis and observation in the field of the different geological structures and materials, of the different geodynamic processes and their relationship with the palaeoenvironments of past eras based on fossils and their traces. Currently, specialized tourism uses this prior knowledge that the society has it so that social groups that show interest in earth science participate in active tourism as a sustainable alternative in which they can deepen and learn while being a tourist in areas of spectacular natural beauty.

In recent decades, laws have been established for the protection of natural spaces as they are places of extraordinary natural heritage, where sustainable environmental education activities are established for their preservation, so that the carrying capacity of visitors, tourism and recreational activities does not degrade the natural resources. These protection and conservation measures have been developed mainly for biological and traditional-cultural resources. However, what happens to the geological elements, which define the geological heritage and its geodiversity? The resources presented in this article show how to enhance and value geological heritage through an itinerary with 3D 
virtual balloons in any natural space. This geological itinerary in field practices allows tourists to participate actively in the teaching-learning process of concepts and processes analyzed in the theoretical part of earth sciences. The educational resources generated are as follows: Virtual itinerary, flight simulator, videos, augmented reality and so on have been developed with Google Earth, facilitating a familiar and effective environment for learning that is implemented in new technologies for daily use in their social groups (smartphone, tablets, ipod and so on) by taking advantage of the motivational power of computer games to achieve the objectives of the specific curriculum of each educational level. This implementation of geological content in an interactive educational and tourist game uses free geomatics applications, constituting an incentive to activate the participant's interest and their spatial vision of the geological reality of the environment they visit.

The aim of this work is to identify, classify and evaluate the most representative geosites at a geological and geomorphological level in the Algarve (Figure 1) and to propose a geological itinerary using $3 \mathrm{D}$ geomatic applications. The new technologies implemented in geomatic tools allow sustainable geotourism and promote the geoconservation of the singular sites of this international touristic destination. Currently, the development of strategies that allow specialized tourism is widely supported. The integration the into society of technologies and social networks through smartphones, tablets and integrated applications (virtual flights, augmented reality, digital cartographies, PGS, Street View, Google Earth, geo-portals and web viewers) [3-5] adapts tourist resources based on scientific and didactic interest that favour the knowledge of the natural environment in which we live in daily and its geological history, allowing this knowledge to value our environment and respect its conservation.

\section{Geological and Geomorphological Setting}

\subsection{Geological Setting}

The Algarve Basin belongs to the southernmost geological province of mainland Portugal, and it is disposed in a latitudinal direction. It extends onshore from Cabo de São Vicente, at the extreme west, to the Guadiana River on the eastern Portuguese-Spanish border. Eastwards of Cabo de São Vicente, beautiful coastal cliffs successively constitute Jurassic, Cretaceous, Miocene and Plio-Quaternary rocks.

In the inland of Algarve, an angular unconformity, with a hiatus of approximately 70 Ma resulting from the Variscan orogeny (closing of a Paleozoic ocean and formation of Pangea), separates the Carboniferous metamorphized and folded flysch rocks from the Triassic continental rocks that constitute the base of the sedimentary infilling of the Algarve basin, related to the erosion of the Variscan Orogen and the beginning of the continental extension which culminates in the separation of African, Eurasian and American plates [6].

Through the Mesozoic, marine sedimentation occured on a continental passive margin formed during the extensional phases of the North Atlantic Ocean opening, after the breakup of the Pangea. In the Jurassic, carbonate sedimentation was well established across the basin and was dominated by shallow water limestones and intercalations of pelagic marls and limestones. During the Lower Cretaceous, clastic and carbonate rocks were deposited in near-shore to continental environments [7].

The stratigraphic contact between the Cenozoic and the Lower Cretaceous represents another hiatus of more than $70 \mathrm{Ma}$ related to the collision of the African and Eurasian plates (Alpine Orogeny). Along the coastal cliffs at the Porto de Mós region between the Zavial and Canavial beaches, a paraconformity can be observed between the Lower Miocene and the Lower Cretaceous strata, while at the Arrifão beach it corresponds to an angular unconformity (sub-horizontal Miocene beds over vertical strata of the Lower Cretaceous) [2].

During the Early and Middle Miocene, the sedimentation occurred in a carbonated ramp of cool-water type. In the Late Miocene, the sedimentation shifted to siliciclastic in relation with the development of the Guadalquivir basin. The following lithostratigraphic units (Figure 2) have been characterized [8]. 


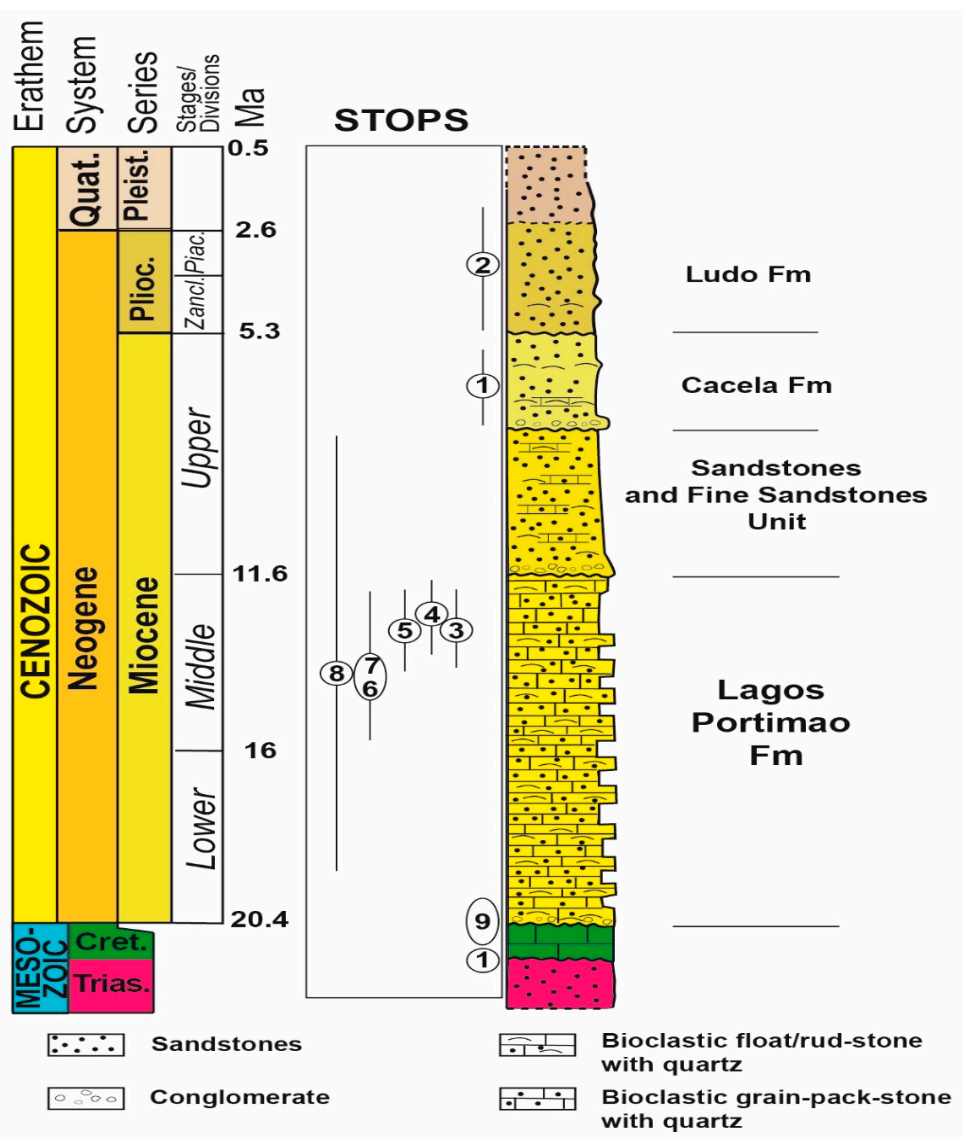

Figure 2. Composite lithostratigraphic scheme for the study area. Numbers refer to distribution of the geosites in Algarve (Figure 1).

(a) Lagos-Portimão Formation (Burdigalian to Serravallian). This Formation outcrops in the coastal cliffs between Lagos and Olhos de Água, consisting of yellowish to pinky, and is very fossiliferous (biocalcarenites with mollusks, bryozoans, echinoids, fishes, crocodiles and cetaceans). The unit presents several internal disconformities that are generally difficult to follow in the terrain and holds angular unconformity, disconformity or paraconformity contacts with the Carboniferous, Jurassic and Cretaceous rocks. Three types of facies were described [9]: (1) fossiliferous sandstone (FS) with bivalves, bryozoans, irregular echinoderms (Clypeaster), heterosteginids, gastropods, starfish and corals, representing the transgressive system tract or the early highstand system tract (shelf, depth 75-90 m); (2) coarse skeletal rudstone (SR) with lithified skeletal grains, balanids, coralline algae, pectinids and ostreids representing the transgressive system tract (mid-shelf, depth 50-75 m) and rhodolith rudstone (RR) with siliciclastic sand, spherical rhodoliths $(5 \mathrm{~cm})$, bivalves and bryozoan representing the photic zone protected from massive swell (inner shelf, 35-50 m).

(b) Sandstones and fine sandstones unit (Lower Tortonian). This unit, also called "Laminated Sands", overlays the Lagos-Portimão Formation by a regional disconformity. It represents a significant sedimentary shift from carbonate to siliciclastic lithologies. At the Rocha beach, the lowest layer is a conglomerate with phosphate clasts and glauconite.

(c) Cacela Formation (Upper Tortonian to Messinian). Outcropping mainly in the eastern sector of the Algarve (Cacela); it consists of conglomerates and limestones with quartz pebbles at the base, passing upwards to carbonate or clayey sands, and it is sometimes enriched in glauconite and bears hundreds of species of mollusks. This unit lies in angular unconformity on the Triassic and in disconformity with the Lagos-Portimão Formation or with the sandstones and fine sandstones unit. 
The Pliocene and Pleistocene are well represented between Praia de Olhos de Agua and the mouth of the Ribeira de Quarteira (Figure 1). At the base of this sucession, there exist the "Falesia marine sands" (a lateral equivalent of the sands of Montenegro) from the Lower Pliocene, which fossilizes a coastal morphology through Miocene paleorelief. At the top of the sequence, the sands of Faro-Quarteira (member of the Ludo Formation -FL) take place: They are made up of medium-grained sands and include a bed with Ostrea gr. lamellosa and Palliolum excisum, a typical Pliocene pectinid [10,11]. This layer, dated to 3 Ma. coincides with a polarity change (reversal to normal) in an immediate upper deposit of silt dated to 2.59 Ma. (lower limit of the Quaternary) [12]. The Ludo formation is made up of four post-Miocene detrital units: sands of Montenegro, sands of Faro-Quarteira, sands of Ludo and sands and conglomerates of Gambelas. The sands of Montenegro belong to the Pliocene (fine white sands), with cross stratification at the base and parallel lamination with bioturbation at the top and are referred to a restricted marine environment such as a gulf or bay, and the Miocene units were of a fluvial environment; the cliffs of the Falesia sands were produced by their erosion.

The Pleistocene is represented by the Faro-Quarteira sands, the Ludo sands and the Gambelas sands and conglomerates. The Faro-Quarteira sands (outcropping in the coastal strip between Faro and Quarteira) are well-sorted and subrounded yellowish sands with few edges and correspond to Plio-Quaternary fluvial and marine sands of shallow continental shelf environment. This formation is similar to the red sands of the Cadiz coast, which have been attributed to the Plio-Quaternary [13-15], currently corresponding to the base of the Pleistocene (Gelasian); they are considered as a heterochronous formation in its base and on the disconformity isochronous of the upper Pliocene with Globorotalia crassaformis. This deposit represents a shallow marine environment with continental influence. It is distributed along the Atlantic coast of Spain and Southern Portugal and associated with the mouths of the main rivers, with a greater extension in the Guadalquivir.

The Ludo sands form channelled deposits over the Quarteira sands, thus presenting a discontinuous spatial distribution and rapid sedimentation of alluvial fan facies, yielding continental gastropods of a lower Pleistocene age. Finally, the sands and conglomerates of Gambelas are interpreted as fluvial sediments of the Middle and Upper Pleistocene.

The Pliocene and Pleistocene tectonic activities are well expressed in the Faro-Quarteira Formation, where normal, inverse and directional faults, as well as folds and structures of plastic deformation, due to subsidence and sismites commonly occur [16]. This tectonic activity shaped not only the type and disposition of the sea cliffs but also the displacement of the coast and the degree of karstification in the affected areas.

\subsection{Geomorphological Setting}

This sector of the Algarve coast presents a general East-West orientation and several high cliffs interspersed with coves with beaches and marine abrasion platforms affected by processes of erosion, fracturing and karstification.

The cliffs are sculpted on calcareous rocks from the Lagos-Portimao Formation, made up of meter-thick beds, generally with a slight dip southwards $\left(<10^{\circ}\right)$. The strata present different lithologies and colorations (sparitic or micritic limestones, biocalcarenites, calcarenites and siltstones, in general), which gives them different competencies and permeability, generating hanging aquifers associated with the more clayey layers that will favor the karstification of these geological materials and the formation of undercuts next to the cliffs.

The cliffs carved by the waves through erosion and collapses present morphological features that could correspond to ancient sea level positions that occurred throughout the Pleistocene. These features refer to undercuts (notch), hanging cave levels and erosive platforms, etc. These hanging marine surfaces are karstified, presenting well-developed slopes on the surface. In front of the cliffs, as witnesses of the marine erosion and retreat of the coast, are islets, pinnacles, cliffs and arches. 
In some coastal sectors associated with the active beaches, there are raised marine platforms oriented according to the direction of the dominant swell (WSW) occurring between the beaches of Galé and Evaristo. In this site, in addition to the current abrasion platform, there are two raised platforms of marine origin. The ages obtained by U/Th in shells of cirripeds (Balanus) allow associating them with two highstands and to the Middle Pleistocene [17].

Another fundamental aspect that conditions the landscape of these areas are the karstification processes that affect, to a greater or lesser degree, all the carbonate materials in this sector. The most characteristic morphologies are karst depressions of different sizes, where the largest can favor the formation of "coves" that separate the associated cliffs and sinkholes of various dimensions. As an example, the surroundings of Carvoeiro beach where you can observe a large sinkhole (left from the sea) and the cove that gives rise to this beach originated in favor of a fracture. The minor depressions, decimetric metric in diameter, have conical shape and depth that, in some cases, connect them with the sea. They appear empty or are filled with detrital sediments (clays and silts) in which more than one deposition phase can be observed, probably occurring or evolving during several Quaternary morphogenetic phases. One of these characteristic forms of dissolution are the so-called dissolution tubes (pipes) that have conical, cylindrical or elliptical shapes; have very different sizes and diameters; and can reach more than a dozen meters. They can be affected by tectonic structures [16] or by stratification planes that make the size and shape of the tubes vary.

There are several theories about the formation of these karst forms, giving more or less importance to groundwater (infiltration), vegetation and the presence of a permeable debris cover [18-22].

The resulting forms of this type of karstification under detrital cover are de-pressures, tubes, ruiniform pinnacles (lapiaces) and kriptodolinas. The Algarve coast can be considered as a cryptokarts where karstification occurs under detrital cover since, on the limestones of the Lagos-Portimao Fm, there are permeable formations (detrital), such as Cacela, Falesia, Faro-Quarteira, Ludo and Gambelas, with a sandy-silty component of marine or continental origin. During the Quaternary, this karst has evolved by being favoured by infiltration waters, hanging groundwater levels, vegetation, geological structures and glacial-interglacial climatic changes. The meteoric waters, by percolation through this detrital cover and with the presence of abundant vegetation, caused the dissolution of the limestone and calcarenitic material, giving rise to decalcification clays that fill the karst depressions and mixing with the detrital material of recent geological formations and with red clays, ("terra rossa") decalcification of calcareous rocks and red soils. Sinkholes and pipes filled with detrital material that can also be brown or blackish-brown in colour, due to being formed during a more humid climate without very dry summers, are associated with glacial or stadials times.

These processes produced during various periods of the Pleistocene result in the increase in size of these karst structures and the creation of new ones.

\section{Materials and Methods}

The first step in this study was the creation of an inventory of the geological heritage elements in the study area, which involves identifying, locating, assessing and classifying the places of interest (i.e., geosites). This inventory must incorporate an analysis of information on the geological features, their variability and the value of the territory in a geological and geomorphological sense [23,24].

Nine geosites (Figure 1) were chosen and analyzed through a methodology of valorizing geological heritage, which values the following 18 parameters $[25,26]$ : representativeness; character type of the site; references in scientific journals; conservation; viewing conditions; rarity; geological diversity; common educational use; population density; accessibility, size, association with other natural or cultural elements, beauty, informative content use; potential for tourism; proximity to recreational areas; and socioeconomic 
structure (Table 1). The intrinsic value of each geosite was scored from 0 to 4 for each one of these parameters and weighted with different coefficients related with their scientific, educational and tourist/recreative interest.

Table 1. Assessment of the parameters for the geosites.

\begin{tabular}{|c|c|c|c|c|c|c|c|c|c|c|c|c|}
\hline & S1 & S2 & S3 & S4 & S5 & S6 & S7 & S8 & S9 & $\overline{\text { SC }}$ & D & $\bar{T}$ \\
\hline Representativeness & 4 & 4 & 2 & 2 & 1 & 4 & 1 & 4 & 4 & 30 & 5 & \\
\hline Character type locality & 2 & 1 & 1 & 1 & 0 & 1 & 1 & 1 & 1 & 10 & 5 & \\
\hline Degree of scientific knowledge about place & 4 & 2 & 4 & 4 & 1 & 1 & 1 & 4 & 4 & 15 & & \\
\hline State of conservation & 1 & 4 & 4 & 4 & 4 & 4 & 4 & 4 & 4 & 10 & 5 & \\
\hline Viewing conditions & 1 & 4 & 4 & 4 & 4 & 4 & 4 & 4 & 4 & 10 & 5 & \\
\hline Rarity & 2 & 2 & 1 & 1 & 0 & 0 & 1 & 1 & 1 & 15 & 5 & \\
\hline Geological diversity & 1 & 2 & 2 & 2 & 2 & 2 & 1 & 2 & 2 & 10 & 10 & \\
\hline Learning objectives/educational use & 2 & 1 & 4 & 4 & 1 & 2 & 0 & 1 & 1 & & 20 & \\
\hline Logistics infrastructure & 4 & 4 & 4 & 4 & 4 & 4 & 4 & 4 & 4 & & 15 & 5 \\
\hline Population density & 2 & 2 & 2 & 2 & 2 & 2 & 2 & 2 & 2 & & 5 & 5 \\
\hline Accessibility & 1 & 0 & 2 & 4 & 4 & 4 & 4 & 4 & 0 & & 10 & 10 \\
\hline Intrinsic fragility & 1 & 1 & 2 & 1 & 2 & 4 & 2 & 2 & 2 & & 5 & 15 \\
\hline Association with elements nature/culture heritage & 2 & 1 & 2 & 1 & 2 & 2 & 2 & 1 & 1 & & 5 & 5 \\
\hline Beauty/spectacularity & 1 & 2 & 2 & 2 & 2 & 4 & 2 & 1 & 1 & & 5 & 20 \\
\hline Informative content/use & 0 & 0 & 2 & 2 & 2 & 2 & 2 & 0 & 0 & & & 15 \\
\hline Potential for activities tourism/recreation & 1 & 1 & 2 & 4 & 2 & 2 & 2 & 1 & 1 & & & 5 \\
\hline Proximity to recreational areas & 2 & 4 & 4 & 4 & 4 & 4 & 4 & 4 & 4 & & & 5 \\
\hline Socioeconomic environment & 0 & 0 & 0 & 0 & 0 & 0 & 0 & 0 & 0 & & & 10 \\
\hline Total & 31 & 35 & 44 & 46 & 37 & 46 & 37 & 40 & 36 & 100 & 100 & 100 \\
\hline
\end{tabular}

The data obtained for each parameter were multiplied by different weighting coefficients depending on the type of value (scientific, didactic or touristic) that is being calculated (Table 2). For the scientific evaluation, parameters were weighted as follows: representativeness-30 points; scientific importance and rarity-15 points; and character of type locality, state of conservation, observation conditions and geological diversity10 points. For the didactic evaluation, parameters were weighted as follows: content or didactic use detectable - 20 points; logistical infrastructure-15 points; accessibility and geological diversity - 10 points; and representativeness, character of type locality and the state of conservation, etc. -5 points. For touristic assessment, parameters were weighted as follows: spectacularity or beauty-20 points; size of the geosite and the content or informative use-15 points; the accessibility and socioeconomic environment-10 points; and observation conditions, logistics infrastructure and population density, etc. -5 points. Figure 2 shows the lithology and geological age of each geosite.

Table 2. Weighted values of the geosites according to their scientific, educational and touristic values.

\begin{tabular}{cccccccccc}
\hline & S1 & S2 & S3 & S4 & S5 & S6 & S7 & S8 & S9 \\
\hline Scientific interest & 260 & 290 & 245 & 245 & 145 & 245 & 160 & 305 & 305 \\
$\begin{array}{c}\text { Educational interest } \\
\text { Touristic/recreational } \\
\text { interest }\end{array}$ & 200 & 200 & 280 & 305 & 235 & 285 & 245 & 250 & 190 \\
\hline Total & 105 & 115 & 210 & 220 & 230 & 300 & 230 & 185 & 130 \\
\hline
\end{tabular}

In order to facilitate the description of the selected elements, the files were expanded in order to contain information about location, type of heritage, uses, maps, diagrams, photographs and description of characteristics, including a semiquantitative analysis refering to site ratings as resulting from the 18 parameters. Various types of information are contained in each file, including descriptive data and assessment data. Assessment data are susceptible to undergo modifications over time. The informative and descriptive 
data include the followign: number and denomination, description, flat location map and orthophoto, representative photographs and geological and geomorphological schemes.

From the identification and assessment of the 9 geosites, the methodology followed for the realization of the virtual itinerary first consisted of a compilation of the digital information of the different thematic layers used for a correct visualization of the described geological heritage. These layers make up geological cartography imported in a vector format and in a KMZ format, as well as a digital elevation model (spatial resolution $5 \mathrm{~m}$ ). The orthophotos and satellite images were obtained from the platform of the National Geographical Institute of Spain in "raster" format. This information was then integrated, using a geographic information system, into the same reference system so that it could be superimposed on a virtual globe.

Then, we proceeded to georeference the different geosites and to create an abbre-viated description for each one (see Supplementary Materials). This involved generating position marks with different symbology and adding field photographs, interpretive schemes and valuation tabs for each site onto the virtual globe. The Google Earth application allows georeferenced geosites to be exported in vector format (points) as a KML layer or to be generated with the "add" menu by using a "placemark" and moving that mark to its exact place (Figure 3). In the properties of each point of geological interest, the user can add a description of the place and add different icons, which allows different thematic itineraries to be expanded (lithological route and active process route, etc.) and to indicate each site with a different symbol color. The user can also add photographs of the outcrop, site, structure or interpreted geological cut. If it is generated with Google Earth, it can be saved using the "save place as" option in the KML or the KMZ format. The online distribution of these points is fast due to their small size (text between 1 and 10 kilobytes and images between 1 and 10 megabytes, depending on the quality of the imported image).

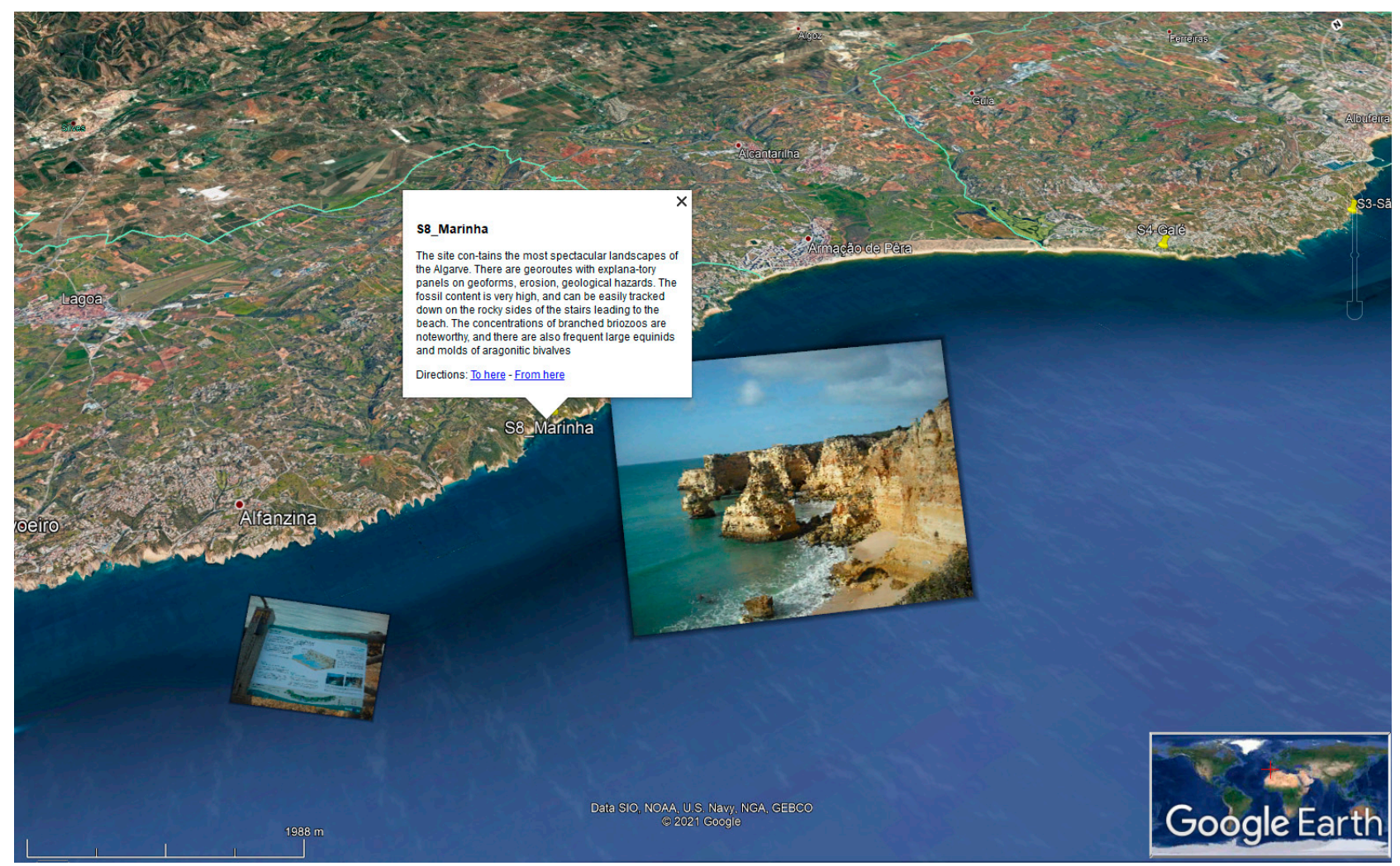

Figure 3. Capture of the geosites of Algarve, which shows the different thematic layers that can be obtained in the itinerary of the geological-geomorphological heritage: thematic cartographies, 3D relief models, block diagrams, diagrams and photographs. 
On the left side of the Google Earth user inferface, the "my places" window allows the user to activate and deactivate each geosite, to modify it and to add new images. The user can zoom in or out on each geosite, and at higher zoom levels the information (texts and images) of the closest points and a descriptive text of the geological-geomorphological interest become visible. The user can provide a degree of transparency to the cartography to overlay elements of the territory that are of interest, such as roads, population centers and more.

Next, we implemented teaching resources to each geosite in such a manner that they are georeferenced and activated for geosite images of the different outcrops, schemes and interpretative drawings, such as topographic profiles in a zone of great fluvial fit and photographical interpretation of outcrops observed from a geosite, photographs and cards with the valuation of each geosite (Figure 3). Photographs were uploaded and displayed when zooming in on the geosite and can activate or deactivate the different resources that help us locate and analyze the site. The superimposition of photographs (unlike the thematic cartographies, which were georeferenced and exported in KML format from GIS for superposition on the 3D globe) was performed by using algorithms integrated in Google Earth, which are able to move the figure both vertically and horizontally in space. This allows the images to be interactively rotated in $360^{\circ}$ and, thereby, visualized from different positions (Figure 4).

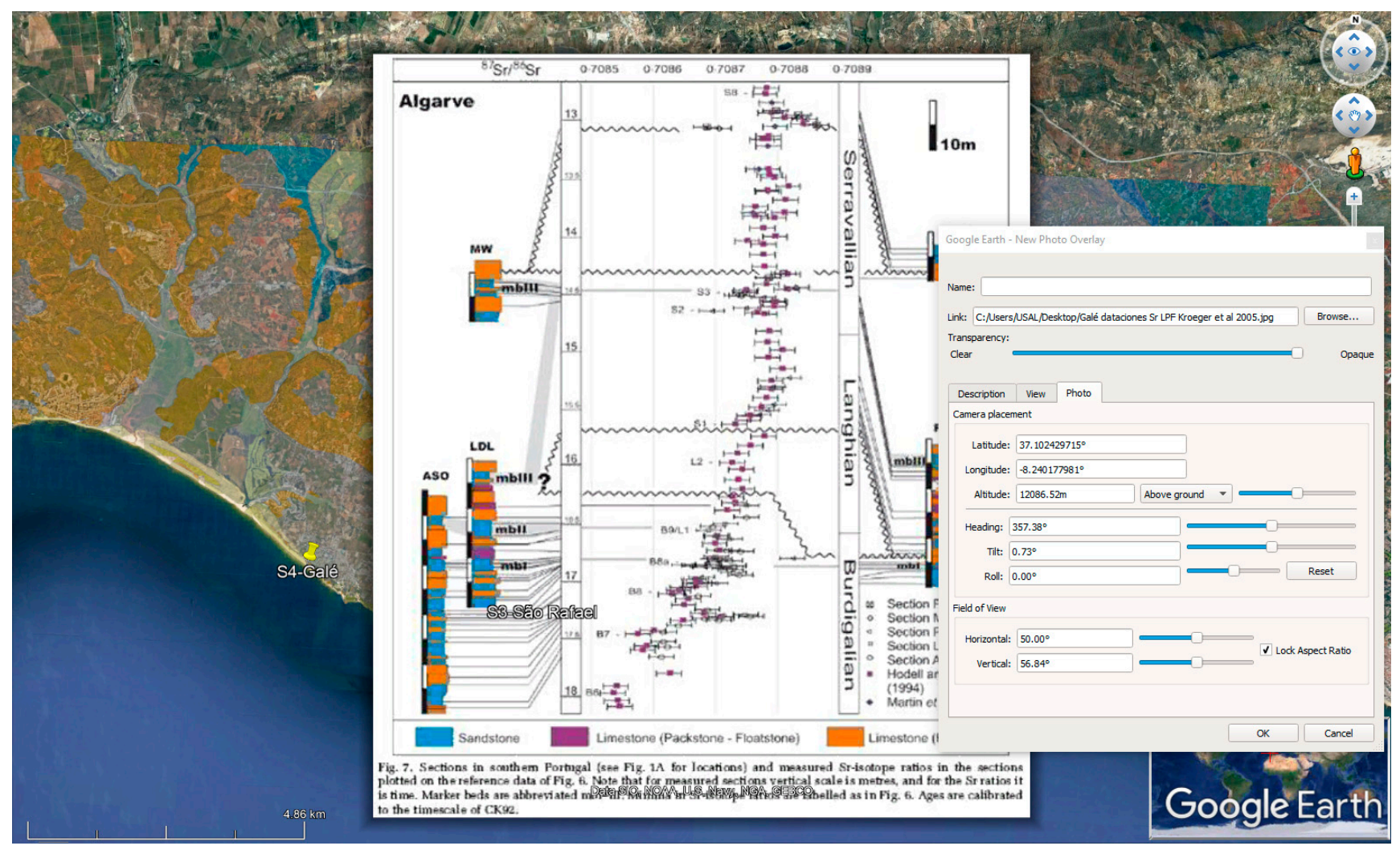

Figure 4. Capture of the Google Earth script that shows the location of the different images on the 3D virtual globe displayed from any mobile application. The pop-up window shows the commands and possibilities of movement that Google Earth offers. Left window [27].

Finally, we loaded digital information into the Google Earth platform in order to establish a series of 3D virtual flights in the itinerary. These were implemented in different formats (mpeg, avi and wma) in order promote reproducibility using different multimedia systems (PC and DVDs, etc.) [28,29]. 


\section{Results and Discussion}

\subsection{Geosites Description and Geoheritage Evaluation}

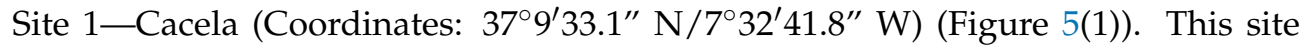
contains the most complete paleontological accumulation of molluscs of the Miocene of Portugal, with well preserved fossils and hundreds of species. Situated between Tavira and Vila Nova de Cacela in the easternmost sector of the barrier islands that constitute the Ria Formosa Natural Park, the site shows the ancient sea cliff protected from current erosion by the barrier islands and their lagoons.

From the end of the 19th century [30], extensive information was obtained relative to its stratigraphy, geological age, taphonomical signature, biogeochemistry, paleoecology, bioerosion, pollen, calcareous nanoplankton, foraminifera, ostracods, mollusks, echinoderms and fish [31-34].

It consists of conglomerates, sands and silts and contains the stratotype of the lower section of the Cacela Fm of late Tortonian age. Actually, the stratotype is in a site that is badly preserved and hardly accesible.

The rating of the site reaches 565 points with a high scientific interest (260) despite its current deteriorated state of conservation and bad conditions for observation, which diminish its educational (200) and touristic / recreational interest (105) (Table 2).

Site 2-Olhos de Agua (Coordinates: $37^{\circ} 5^{\prime} 22^{\prime \prime} \mathrm{N} / 8^{\circ} 10^{\prime} 39^{\prime \prime} \mathrm{W}$ ) (Figure 5(2)). The geosite's name is due to the occurrence of freshwater upwellings due to small hanging aquifers resulting from lithological changes between detrital and carbonate facies at the base of the cliff. In this site, $50 \mathrm{~m}$ of white, yellow and reddish continental sandy sediments with some intercalated clays and conglomerates of the Pliocene-Pleistocene age can be observed (Falésia beach cliffs). They disconformably overlaid the biocalcarenites of the LagosPortimao Formation. The presence, unique in the whole Algarve, of a sandy marine level located at about $30 \mathrm{~m}$ height is remarkable (red arrow in the figure), and it contains eroded fossils of aquatic vertebrates (fish, bones of cetaceans) and mollusks dated 3 million years.

Differences between the rocky cliffs to the west of this point and the sandy ones to the east are due to the effect on the sedimentation of two large fractures that delimit the area: The first is the Quarteira, NW-SE (fault in direction, dextral, with an inverse component towards the coast), which separates this region of the Algarve into two zones (E and $\mathrm{W}$ ) where the eastern one has detrital littoral sediments (Pliocene and Quaternary) and the western one has carbonate (Miocene, Paleocene, Triassic and Cretaceous). The second is the Albufeira fault, N-S, which delimits this depressed sector to the west.

At the top of the Olhos de Água cliff, one can observe, towards the east, the receding sandy cliff that limits Praia da Oura where the erosion of the upper part of the beach gives rise to a series of sediments from the Upper Pleistocene and Holocene of the alluvial cones type; colluviums on the slope of the cliff; mass movements (landslides and falling blocks) due to the grounding of the base; and rotational sliding favoured by the presence of fractures that delimit this sector and by the seismic activity of this area (Figure 5(3a)).

The site reaches 605 points, of which 290 correspond to scientific interest, 200 to educational interest (it is difficult to reach the fossiliferous level) and 115 to tourism interest.

Site 3-Sao Rafael-Castelo beaches (Coordinates: $37^{\circ} 4^{\prime} 25.8^{\prime \prime} \mathrm{N} / 8^{\circ} 16^{\prime} 57.2^{\prime \prime} \mathrm{W}$ ) (Figure 5(3)). The site is located between Sao Rafael beach to the westernward Castelo beach. The area has plentiful fossils, which form concentrations of corals associated with briozoans, rhodolites (Figure 5(3a)), pectinids and echinoids. The transition between the two first fossil concentrations could be related to a prominent Miocene climate change [35]. 

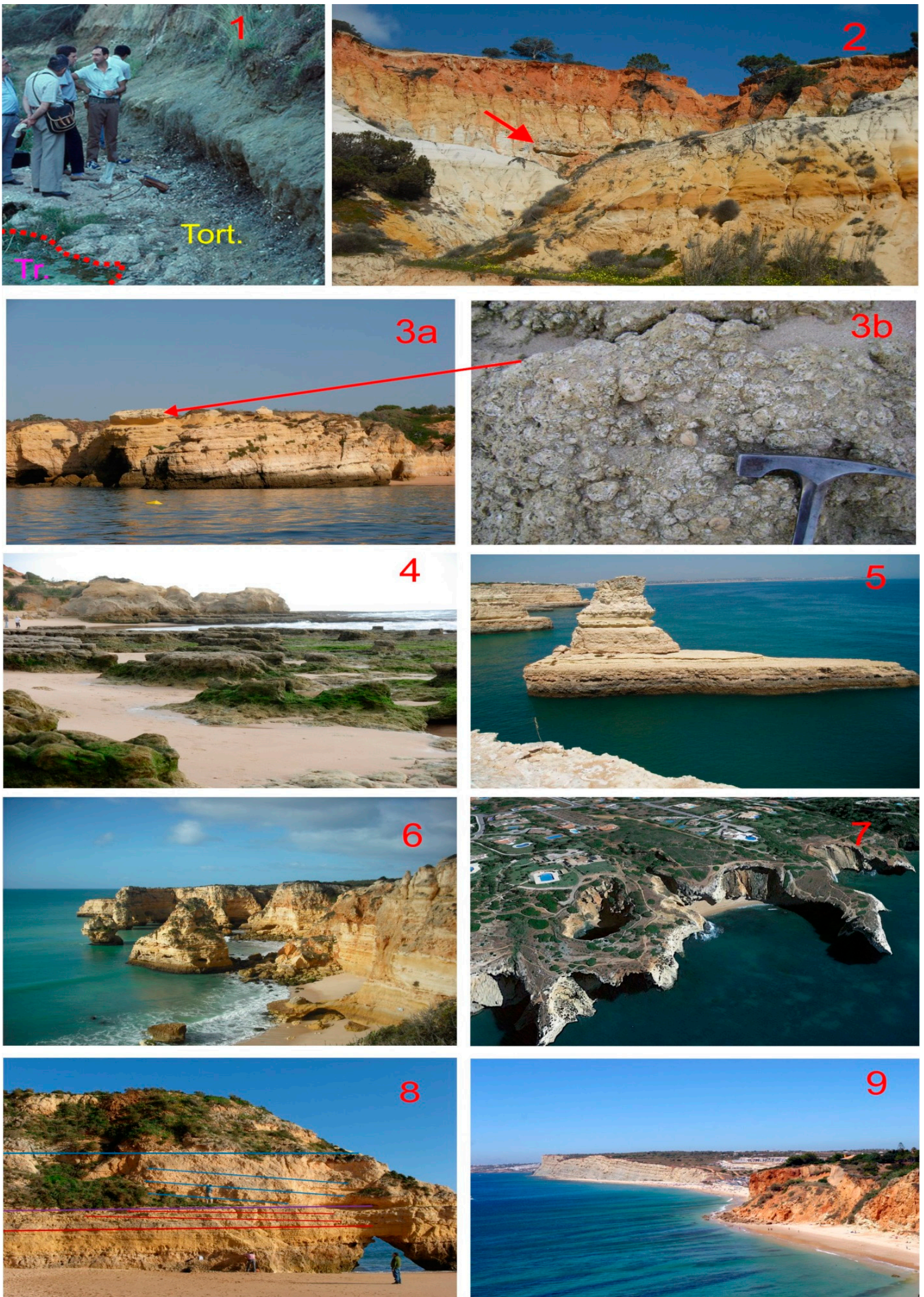

Figure 5. Geosites studied: (1)—Cacela (boundary between Triassic and Tortonian units); (2)—Olhos de Agua; (3a)—S. Rafael; and (3b)—detail of the rodolites concentration; (4)—Galé; (5)—Senhora da Rocha; (6)—Marinha; (7)—Carvoeiro; (8) -Vau-Rocha; (9)—Canavial. 
The geomorphological peculiarity is that it consists of small coves with carved vertical cliffs, where erosion causes entrances that look similar to marine undercuts. Karstifications represented by depressions with or without sediment are observed, with typical morphologies that have been called algares, poches (erosions filled under permeable sediments), pipes (dissolution tubes) or sinkholes. Most of them were formed under a detrital cover, which is why they appear as collapses filled with sediments on the surface (from that cover) due to the presence of hanging water tables or by the sea level at the time of their formation. In other cases, erosion exhumed them. These depressions can be related to old or recent fractures, which give rise to areas of weakness and facilitate the dissolution of calcareous deposits. The presence of two orthogonal fracture systems favours the dissolution of limestone, affecting the fill materials, with sediment displacement on both sides of the fractures [22]. Empty or infilled depressions and various phases of sedimentary fillings can be observed.

The weighted evaluation reaches 735 points, with 245 in scientific value, 280 in educational value and 210 in tourist value.

Site 4-Galé beach (Coordinates: $37^{\circ} 4^{\prime} 50.2^{\prime \prime}$ N/8 $8^{\circ} 18^{\prime} 59.2^{\prime \prime} \mathrm{W}$ ) (Figure 4). The site near the beach with very low relief allows the observation of many fossils of the upper section of Lagos-Portimão Fm LPF with unique pyramidal morphologies (Figure 6E). At low tide, three staggered platforms of marine wave erosion (P1-P3) stand out [12]. The P1 is the best-preserved, with a height of its maximum tidal amplitude of $+5 \mathrm{~m}$. Moreover, the same concentration of rhodoliths of site two is observable. All the outcrops are very rich in fossils (mainly mollusks) and stand out centimetrical levels with large flat irregular Echinoids (Scutella) or with spectacular fossil traces of crustaceans (Thalassinoides).

The valuation attains 770 points, the second highest of the Algarve, with 245 (scientific), 305 (educational, as it is very accessible and commonly used in field practices by several Universities) and 220 (touristic/recreational) values.

Site 5-Senhora da Rocha (Coordinates $37^{\circ} 5^{\prime} 44.75^{\prime \prime} \mathrm{N} / 8^{\circ} 23^{\prime} 23.13^{\prime \prime} \mathrm{W}$ ) (Figure 5). The site includes the watchtower where the small hermitage of Nossa Senhora da Rocha is located and from which there is a good overview of the vertical cliffs of the area, constituted by sandstones and carbonates of the LPF. Some morphologies resemble various objects, such as the so-called submarine (Figure 5). Tectonic displacement and weathering processes can be observed. In the nearby beach, which can be reached by stairs access, there are concentrations of fossils, especially pectinids.

Inland and on the structural surface of the top of the LPF, detrital sediments of the Faro-Quarteira Formation can be observed to be eroding the carbonate sequence. On it are numerous relevant karstifications, filled or not filled with sediments of different Quaternary ages (deduced by its degree of crusting and types of rubification of the filling deposits). One of them consists of a huge tube that descends from the top of the cliff to the beach, which has been used to build the descending staircase (Figure 6F). From the base of the cliff, there are several alignments of horizontal conduits at different heights $(+1 \mathrm{~m},+3 \mathrm{~m}$ and $+5 \mathrm{~m}$ ) that could be due to the presence of hanging aquifers and/or to successive variations in sea level (water table) in the last interglacial (Figure 6F).

The value as geosite is 620 points of which 145 correspond to the scientific interest, 235 to the didactic and 230 to the touristic-cultural.

Site 6-Marinha beach (Coordinates: 37 $5^{\prime} 23.8^{\prime \prime} \mathrm{N} / 8^{\circ} 24^{\prime} 41.26^{\prime \prime} \mathrm{W}$ ) (Figure 5(6)). The site offers the most spectacular landscapes of the Algarve. There are georoutes with explanatory panels on geoforms, erosion and geological hazards. The fossil content is very high and can be easily tracked down on the rocky sides of the stairs leading to the beach. The concentrations of branched bryozoans are noteworthy, and there are also frequent large echinoids and molds of bivalves. 

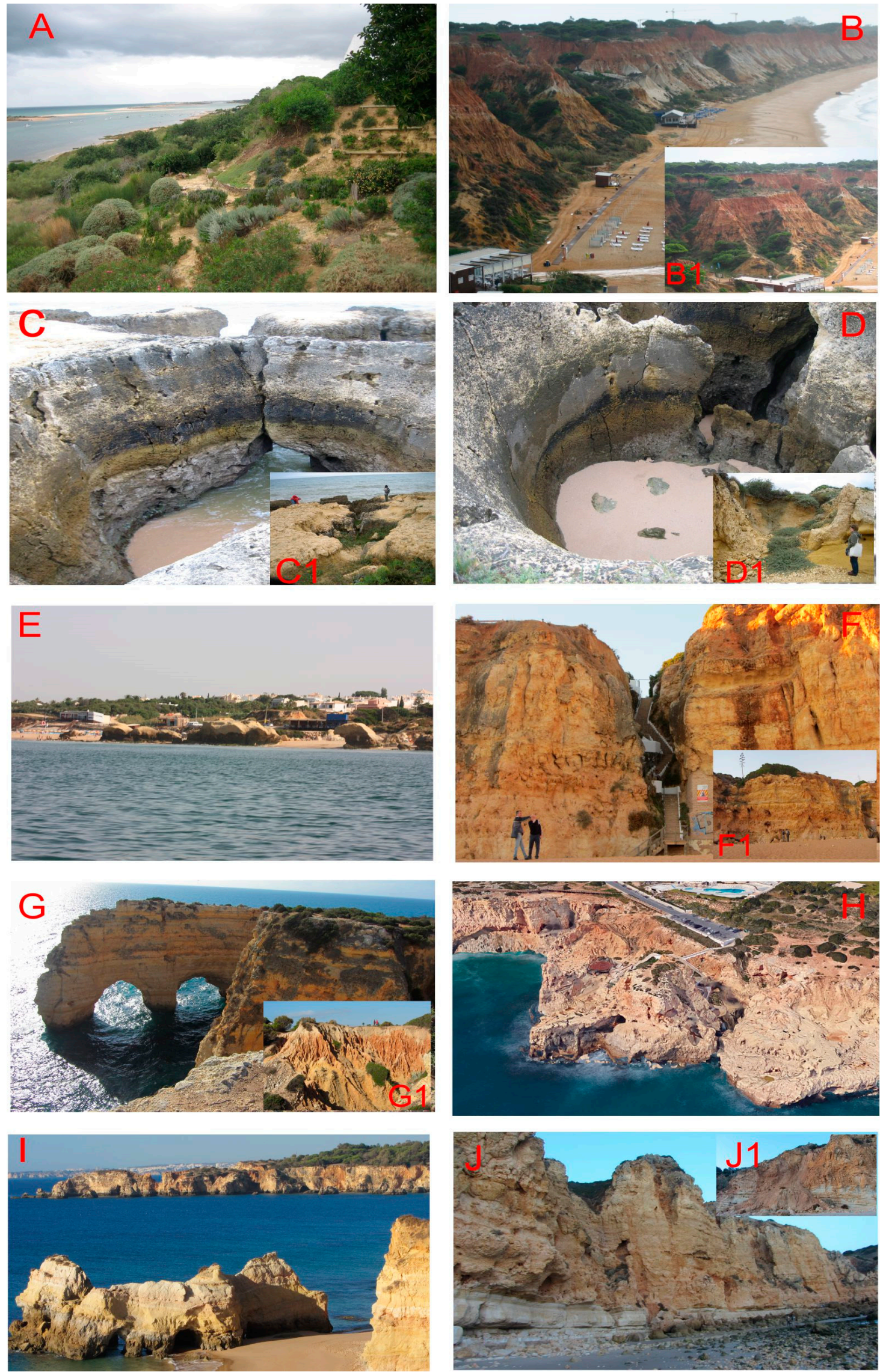

Figure 6. Geomorphological features of the selected sites. (A): Site 1 (Cacela); fossil cliff, protected by barrier islands and 
lagoons. (B): Site 2 (Olhos de Agua); panoramic of the sandy cliff. (B1): Detail, with a gravitational slip. (C): Site 3 (S. Rafael-Castelo). West of São Rafael beach: Algares, dry and connected to the sea; lapiaz developed on the surface. (C1): Sites affected by fractures. (D): Site 3 (S. Rafael-Castelo); circular buckets without old sediments. (D1): Infilled sinkhole; (E): Site 4 (Galé); marine cliff and pyramidal morphologies. (F): Site 5 (Senhora da Rocha); karstic pipe used to install the staircase down to the beach. (F1): Cliff with alignments of horizontal conduits observable at different heights. (G): Site 6 (Marinha); structural surface and arches of marine origin. (G1): Badlands and landslides. (B1): Cárcavas over red sands of Faro-Quarteira Fm. (H): Site 7 (Carvoeiro); panoramic view of Algar Seco. (I): Site 8 (Vau-Rocha); unconformity and platform favouring caves and undercuts. (J): Site 9 (Canavial); unconformity between LPF and the Cretaceous. (J1): Landslide.

The contour of this beach is constituted by rocks of LPF, covered inwardly by detrital sediments of the Falesia-Quarteira Fm FQF (red sands; Figure 6G), which erode its structural surface. There are numerous small streams that, when reaching the beach, give rise to small coves. The walls surrounding this beach represent receding sea cliffs that are very vertical as a consequence of the marine erosion that affects their base (undercutting), with setbacks in winter that result in originate blockages, landslides and debris cones accumulated at its base. The action of the waves resulted in islets separated from the cliff face, caves at the base of the cliff and arches of singular beauty (west sector) (Figure 6G).

The value of the geosite is the highest out of those studied, reaching 830 points of which 245 points were of the scientific interest, 280 points for educational interest (the maximum) and 300 points for touristic-recreational interest (maximum).

Site 7-Carvoeiro (Coordinates: $37^{\circ} 5^{\prime} 44.77^{\prime \prime} \mathrm{N} / 8^{\circ} 22^{\prime} 18.72^{\prime \prime} \mathrm{W}$ ) (Figure 5(7)). This site, also of great scenic beauty, includes the Tres Castelos and Carvoeiro beaches, and the easternward place called "Algar Seco" (Figure 6H), a karstic cavity of tourist interest for its morphology. The sediments of the LPF are rich in fossils, namely levels of concentration of the pectinid Chlamys.

Três Castelos beach originated from a fracture that limits it to the west (Figure 5(7)), giving rise to an asymmetric cove surrounded by high LPF cliffs. At the base of the cliff, a series of sea shelters, caves and arches has arisen. As the most relevant karstifications, we must highlight the great collapse sinkhole in favour of a large open vault in the underground complex, carved by the current sea and the Algar Seco. The presence of karst tubes is significant, both on the upper level of the cliff and at its base. In the tourist site of Algar Seco, karst fillings of red decalcification clays can be observed at its base, as well as lattice carbonates at the top.

The geosite has been valued at 635 points, of which 160 correspond to the scientific interest, 245 to educational and 230 to tourist-recreational interest.

Site 8-Praia da Vau-Rocha (Coordinates: $37^{\circ} 6^{\prime} 57.02^{\prime \prime}$ N $/ 8^{\circ} 32^{\prime} 45.47^{\prime \prime}$ W) (Figure 5(8)). The site displays an architecture (stacking and morphology of the strata) with three types of sequences of eustatic origin, Orbital origin (Milankovitch cycles) and caused by storms. Sedimentary structures also suggest superficial currents from the Mediterranean to the Atlantic (inverse to the present one) [36,37].

From a panoramic view (Figure 5), one can observe in the background the sea cliff with caves at its base and karstifications on the top. In the foreground, an islet with marine arches and caves can be observed.

The geosite reaches 725 points, of which 305 correspond to the scientific interest (the maximum), 250 to the educational and 170 to the touristic-cultural interest.

Site 9-Canavial beach (Coordinates: $37^{\circ} 5^{\prime} 1.64^{\prime \prime} \mathrm{N} / 8^{\circ} 40^{\prime} 40.79^{\prime \prime}$ W) (Figure 5(9)). On the western coast of Lagos, the basal levels of the yellowish biocalcarenites of LPF outcrop rest in sligth angular unconformity (or apparent paraconformity) over the carbonate Lower Cretaceous units. The stratigraphic contact is highlighted by a ferruginous hardground and bioerosional structures [36]. The most abundant fossils are bryozoans, mollusks, echinoids and rhodolits.

The marine cliff has very hilly vertical walls (Figure 6J), is very karstified in its upper part and has a ruiniform appearance with very irregular depressions and tubes with and 
without sediments. The cliff is punctuated with quaternary deposits of gravitational origin (landslides, falling blocks and avalanche cones) (Figure 6J).

The geosite reaches 625 points, 300 of scientific interest (the maximum), 190 educational and 130 touristic interest.

\subsection{Three-Dimensional Virtual Itinerary with Augmented Reality}

With respect to unweighted values, they range between 31 points from Cacela (S1) and 46 points from Galé and Marinha $(\mathrm{S} 4, \mathrm{~S} 6)$. All the sites, except Cacela, stand out for their extraordinary state of conservation, viewing conditions and proximity to recreational areas, reaching the highest score of (4). The best accessibility is presented by sites $\mathrm{S} 4$ to $\mathrm{S} 8$, easily accessible even by bus. Sites S1, S3, S4, S8 and S9 are well known by the international geological scientific community because they have been the subject of publications in international scientific journals included in the Scientific Citation Index. All the sites present high geological diversity, except S1 (Cacela, which is mainly of paleontological interest). Although they all score in the parameter "Beauty/spectacularity", site S6 (Marinha) is known as the most beautiful landscape in the area (Figure 5(6) and Figure 6G). The highly logistical infrastructure for promoting tourism means that all sites have the highest score in this parameter. Likewise, the population density in the entire coastal zone reaches a value of two points for all sites. On the contrary, the socio-economic conditions of the Algarve, which are higher than the national average, mean that this parameter has the minimum value (0) in all cases. This value is also reached for the parameter "Informative content/use" in sites S1, S2, S8 and S9 due to the absence of informative elements in situ about the geology of the site.

Considering the weighted values, the sites with the highest valuation for geological heritage are S6 (Marinha, 830 points), S4 (Galé, 770) and S8 (Rocha, 740). The most prominent for their scientific interest are S8 (Rocha) and S9 (Canavial), with a value of 305, and S2 (Olhos de Agua), with a value of 290. Values of more than 266 are indicative of very high scientific interest. These are places that were the subject of numerous scientific publications and have been part of field trips in several international conferences related to geology. The other six sites selected are of high scientific interest $(133<$ Scientific value $<266)$. The sites with higher values for their educational interest are S4 (Galé, 305), S6 (Marinha, 285) and S3 (São Rafael-Castelo, 280). Values of more than 266 indicate of very high educational interest. All are well preserved, easily observed, accessible, with geological diversity, informative panels on observable geology and regularly visited by national and international primary, secondary and university students. The other sites selected are of high educational interest $(133<$ Educational value $<266)$.

In an area such as the Algarve, which is internationally known for its tourist attraction, the site with the highest touristic/recreational value in its geological heritage is S6 (Marinha, 300 pts, very high touristic interest) because its beauty and accessibility make it a very visited and well-cared place by tourists, and it also contains infrastructure to prevent degradation. Moreover, S7 (Algar Seco) and S5 (Senhora da Rocha) are also noteworthy, both with $230 \mathrm{pts}$. Site 7 represents a very visited place due to its peculiar geomorphological configuration and the geological information presented in panels. Concerning S5, the most remarkable thing for tourists is the spectacular panoramic view that can be observed from the Hermitage of Nossa Senhora da Rocha, including unique morphological forms such as the one known as "Submarine" (Figure 5(5)). Sites S7, S5, S4, S3 and S8 are considered to possess high touristic interest $(133<$ Touristic value $<166)$. Sites S9, S2 and S1 are considered to possess medium touristic interest (Touristic value $<133$ ) mainly related to their accessibility difficulties.

The large number of geosites identified shows the great geological diversity existing in these natural spaces of South Portugal. Geological itineraries have been developed in each natural space based on the nine geosites identified. The most representative sites were then determined by using scientific, didactic and touristic contexts, which allows us to identify and interpret the singularities of the existing geological elements in each natural space. 
The layout of each itinerary generated in this work can be followed in real time using mobile devices. In this manner, part of the information that is currently presented in panels, posters, brochures and guides could be replaced by augmented reality, which allows open digital documentation in addition to photographs, diagrams, graphics and terrain profiles to be displayed for each geosite (Figure 7). The use of GPS incorporated in mobile devices (smartphones, tablets and PDAs, etc.) allows the user to obtain up-to-date information about the situation regarding the routes for each one of the geosites of interest. For each geosite, by activating the "thumbtack," it is possible to open a description of the point on a virtual globe and, in the same window, to mark routes between geosites, which allows the best route to be determined or to realize a thematic itinerary. For example, traversing geosites with paleontological particularities provides freedom to the user to follow their interest at the different stops in Supplementary Materials along the route (Figure 8).

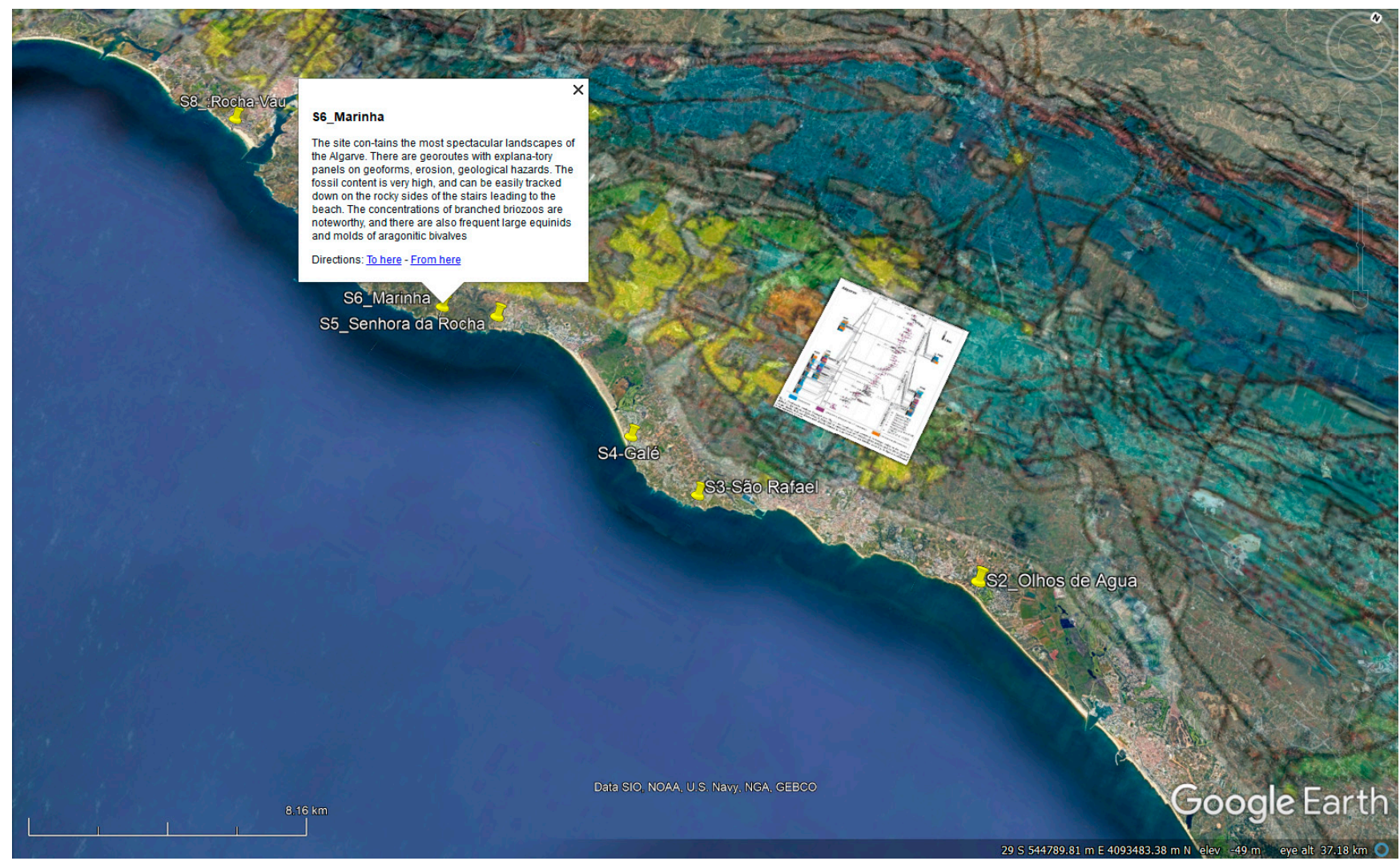

Figure 7. Capture of the geosites in the natural space of Marinha-Galé-Sao Rafael. Images of the location of some stops on geologic cartography and interpretive schemes are shown.

The free Google Earth platform allows the recording of video (Figure 9) for the itineraries in which all the resources can be implemented (photographs and diagrams, etc.) so that it can be exported to common video formats, which allow wide diffusion such as mpeg and avi. This allows the video to be reproduced on computer systems (PC and Mac, etc.) and non-computer media (DVDs, Hard Drives and multimedia, etc.), which facilitates the enhancement and globalization of the geological heritage of these natural spaces. These virtual techniques facilitate teaching-learning processes by awakening creativity and imparting knowledge, as well as improving interactive skills and abilities when using new technologies. The type of itineraries mentioned here allows geological tourism and, more generally, "geotourism" to be enhanced and can also be used for the planning, management and valuation of geological resources, which attracts specialized tourism and generates employment in sectors of great natural beauty in addition to being sustainable. 


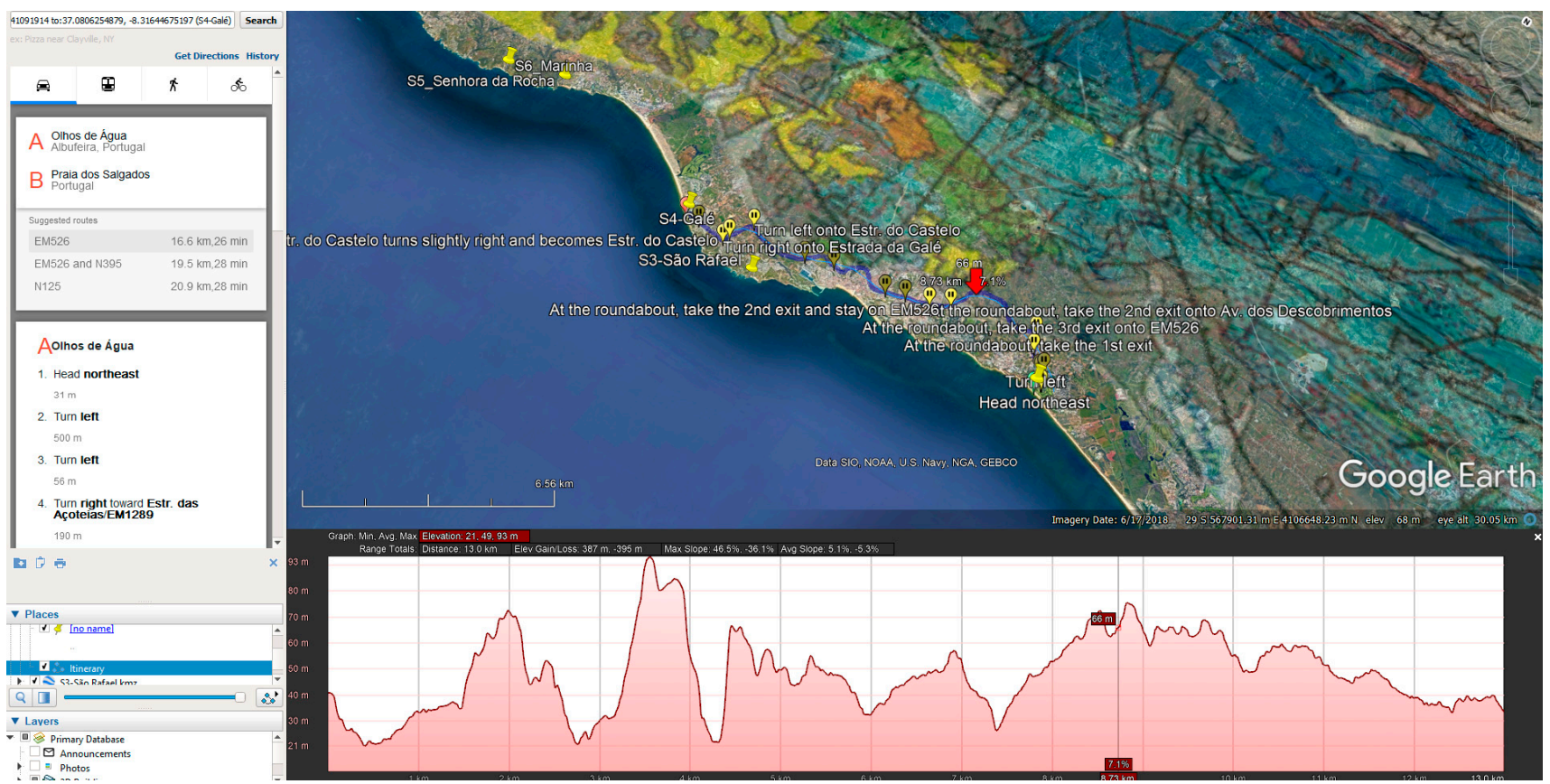

Figure 8. Capture showing the route generated automatically between geosite Olhos de Agua and Gale. The possibility of choosing to realize the route by car, bus, bicycle or by walking can be observed in the left part of the image. It also shows the time and the indications as we move. In the lower part of the table of contents, we observe the loaded thematic layers on which the studied placemarks are superimposed. Profile routes with elevation and slope are included in the itinerary.

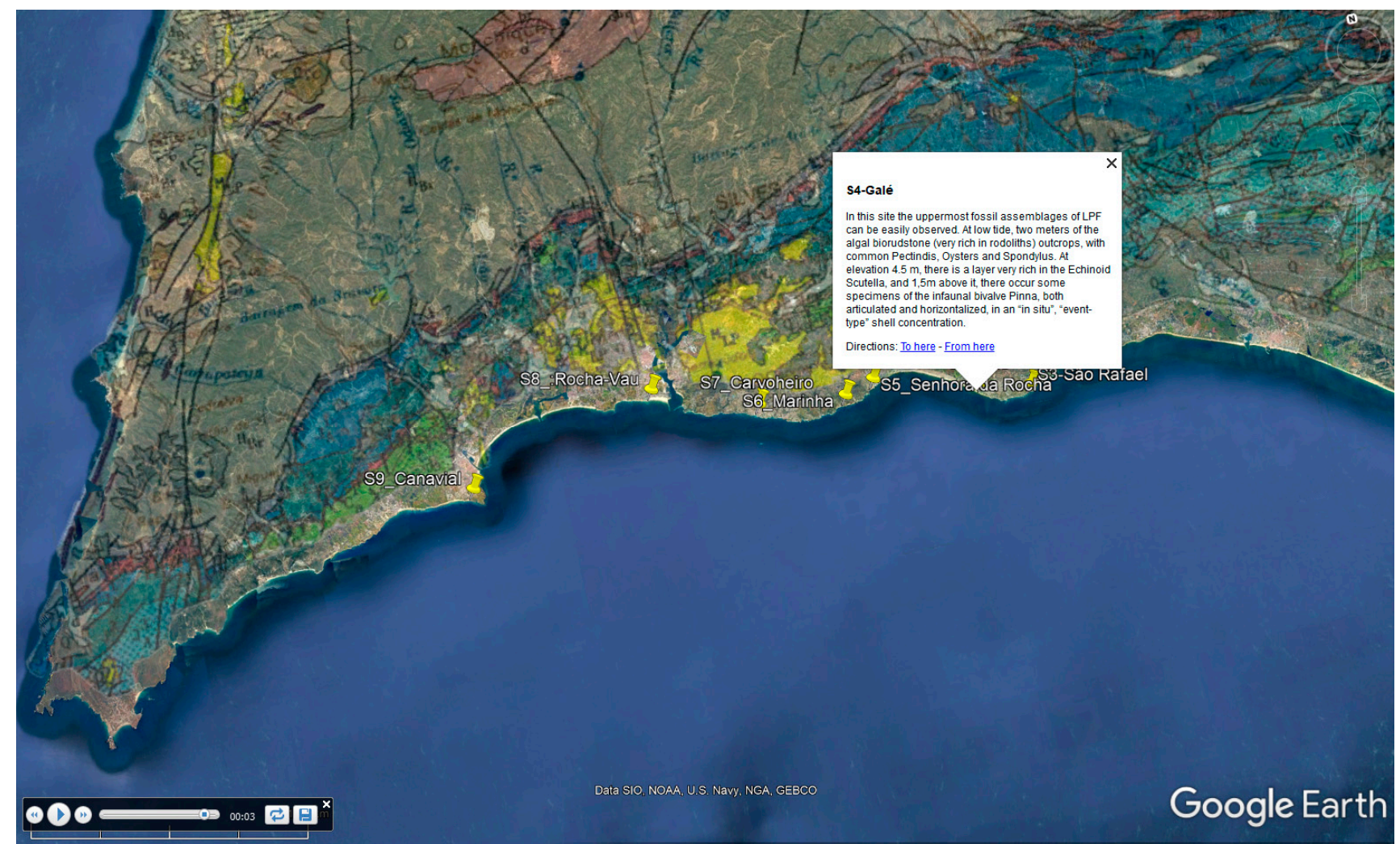

Figure 9. Image showing the video playback commands on the left side, the fast-forward to the left and right and the button for saving the video. 


\section{Conclusions}

Geological heritage is an educational resource for which enhancement allows awareness and sensitivity towards the environment as well as an understanding of the role of men in nature, raising awareness with respect to his environmental responsibility. This article highlights the geological heritage using geological itineraries with 3D virtual balloons and field practices, allowing participants/tourists to actively participate in the teachinglearning process of concepts and processes analyzed in the theoretical part of the subjects in the science of the earth. The educational resources generated, such as virtual itinerary, flight simulator, videos and augmented reality, have been developed with Google Earth, facilitating a familiar and effective environment for learning that is implemented in new technologies for daily use in their respective social groups (smartphone, tablets and ipod), taking advantage of the motivational power of social networks and computer games to achieve specific interests that favor geotourism and geo-education in areas of great environmental value, such as the Algarve.

The Portuguese Algarve coast, intensely used by tourism, presents the following: (1) unique geomorphological and landscape aspects, many of them related to tectonics; (2) a peculiar stratigraphic architecture containing a wide variety of lithologies and colours contribute to the spectacularity of these landscapes, which has been interpreted as a record of global changes related to orbital variations; (3) an important content in macrofossils of many taxonomic groups; (4) evident and observable examples of coastal geological hazards. These characteristics make up the valuation of geological heritage and can reach high scores either globally or by assessing the scientific, educational and touristic-recreational interest.

With respect to both scientific and educational interest, three of the nine geosites evaluated have very high interest, and the other six are considered of high interest. Considering their touristic values, only Marinha has very high touristic interest, five sites have high touristic interest and the geological heritage of three sites have medium touristic interest.

The methodology described is compatible with the implementation of geological heritage cartographies in web applications, viewers and geoportals, which allows the different thematic layers generated in this study to be supported in various virtual viewer and geoportal applications that are both free (Google Earth) or purchased (Terra Explorer). The attainment, management, analysis, representation and graphical outputs of the thematic information are favored: geology, geomorphology and geological heritage georeferenced by means of the "dump" of this digital geodatabase into a newly created spatial data infrastructure (IDEs) or "hanging" of already created spatial data infrastructures (European, national and regional administration), which facilitates the use of "augmented reality" for which its purpose is to visualize and manage information through an Internet browser, a mobile phone, a PDA or a laptop. Users can search for, visualize and combine information about the geological heritage and geodiversity. This methodology is intended to disseminate heritage information and to apply geospatial resources in research, education, didactic and geotourism applications for their value and conservation.

The teaching resources used help make the tour more entertaining and educational for the participans. In addition, the geomatics applied with the tools available on the Google Earth platform allows implementing augmented reality in a smartphone for daily use in student life and allows interaction with the generated resources such as the flight simulator, 3D maps and Street View, among others.

The implementation of these geo-resources in new technologies allows a more sustainable tourism, a better knowledge of the territory in which we live in daily and allows greater geoconservation of our natural environment since, with this procedure, non-renewable resources and looting are avoided in these geoheritage resources, producing a territory with greater cultural value.

Supplementary Materials: The following are available online at https:/ / www.mdpi.com/article/10 $.3390 /$ land10090918/s1, Kmz geosites. 
Author Contributions: Conceptualization, A.M.-G., P.L., J.A.G.-D. and J.L.G.; methodology, I.A.; software, P.L. and A.M.-G.; validation, A.M.-G., P.L., J.A.G.-D. and C.Z.; formal analysis, A.M.-G., C.D., J.A.G.-D. and J.L.G.; investigation, A.M.-G., C.D., J.A.G.-D. and J.L.G.; resources, A.M.-G., P.L., J.A.G.-D. and C.D.; data curation, A.M.-G., J.L.G., J.A.G.-D. and C.Z.; writing-original draft preparation, J.L.G. and A.M.-G.; writing-review and editing, C.D. and A.M.-G.; visualization, C.D. and A.M.-G.; supervision, J.A.G.-D.; project administration, A.M.-G.; funding acquisition, A.M.-G. All authors have read and agreed to the published version of the manuscript.

Funding: This research received no external funding.

Acknowledgments: This work was supported by the Diputación de Salamanca (Salamanca County Council) through the Tourism Area (Key Code VB8C), the GEAPAGE research group (Environmental Geomorphology and Geological Heritage) of the University of Salamanca and support the from Fundação para a Ciência e Tecnologia (FCT) UIDB/04035/2020 is also acknowledged. The authors would also like to thank the editor and the three reviewers who have supervised and improved the article with their constructive suggestions.

Conflicts of Interest: The authors declare no conflict of interest.

\section{References}

1. Oliveira, S.; Moura, D.; Boski, T.; Horta, J. Coastal paleokarst landforms: A morphometric approach via UAV for coastal management (Algarve, Portugal case study). Ocean. Coast. Manag. 2019, 167, 245-261. [CrossRef]

2. Pais, J.; Cunha, P.P.; Pereira, D.; Legoinha, P.; Dias, R.; Moura, D.; Brum, A.; Kullberg, J.C.; González-Delgado, J.A. The Paleogene and Neogene of Western Iberia (Portugal): A Cenozoic Record in the European Atlantic Domain. Springer Briefs Earth Sci. 2012, 1, $1-138$.

3. Martínez-Graña, A.; González-Delgado, J.; Pallarés, S.; Goy, J.; Civis Llovera, J. 3D virtual itinerary for education using Google Earth as a tool for recovery of the geological heritage of Natural Areas: Application in the "Las Batuecas Valley" Nature Park (Salamanca, Spain). Sustainability 2014, 6, 8567-8591. [CrossRef]

4. Brilha, J. Inventory and quantitative assessment of geosites and geodiversity sites: A review. Geoheritage 2016, 8, 119-134. [CrossRef]

5. Martínez-Graña, A.M.; Goy, J.L.; Cimarra, C. 2D to 3D geologic map transformation using virtual globes, flight simulators, and their applications in the analysis of geodiversity in natural areas. Environ. Earth Sci. 2015, 73, 8023-8034. [CrossRef]

6. Terrinha, P.; Rocha, R.; Rey, J.; Cachão, M.; Moura, D.; Roque, C.; Martins, L.; Valadares, V.; Cabral, J.; Azevedo, M.R.; et al. A Bacia do Algarve: Estratigrafia, Paleogeografia e tectónica. In Geologia de Portugal no Contexto da Ibéria; Dias, R., Araújo, A., Terrinha, P., Kullberg, J.C., Eds.; Sociedade Geológica de Portugal \& Universidade de Évora: Évora, Portugal, 2006 ; pp. $247-316$.

7. Reynard, E.; Brilha, J. (Eds.) Geoheritage: Assessment, Protection, and Management; Elsevier: New York, NY, USA, 2017.

8. Antunes, M.T.; Pais, J. The Neogene and Quaternary of Algarve. Ciências Da Terra 1992, 2, 57-72.

9. Antunes, M.T.; Elderfield, H.; Legoinha, P.; Pais, J. The Neogene of Algarve. In González-Delgado, Sierro E Pais (Coord.): The Guadalquivir Basin and Algarve, Field Trip Guide 2; IV RCANS Congress: Salamanca, Spain, 1997.

10. Pais, J.; Legoinha, P.; Elderfield, H.; Sousa, L.; Estevens, M. The Neogene of Algarve (Portugal). Ciências Da Terra (UNL) 2000, 14, 277-288. Available online: http:/ /hdl.handle.net/10362/4720 (accessed on 11 December 2020).

11. Porta, J. Distribución geográfica y cronoestratigráfica de Palliolum (Lissochlamys) excisum en España. Acta Geol. Hisp. 1979, 14, 370-374.

12. Moura, D.; Albardeiro, L.; Veiga-Pires, C.; Boski, T.; Tigano, E. Morphological features and processes in the central Algarve rocky coast (South Portugal). Geomorphology 2006, 81, 345-360. [CrossRef]

13. Zazo, C. El problema del limite Neógeno-Cuaternario del S y SE de España. Trab. Sobre Neógeno-Cuatern. 1979, 9, 65-72.

14. Zazo, C.; Goy, J.L.; Hoyos, M.; Meco, J.; Usera, J.; García Vicente, J.; Galván, J.; Aguirre, E. El corte de Puerto Real y el problema del limite Plio-Pleistoceno en la Bahía de Cádiz. Trab. Sobre Neógeno-Cuatern. 1977, 6, 319-336.

15. Moura, D.; Boski, T.; Dias, R. Sedimentacao detritica durante o Pliocenico e pleistocénico no Algarve Central. Comun. Inst. Geol. E Min. 1998, 84, A177-A180.

16. Dias, R.P.; Cabral, J. Interpretation of recent structures in an area of cryptokarst evolution-Neotectonic versus subsidence genesis. Geodinámica Acta 2002, 15, 233-248. [CrossRef]

17. Moura, D.; Gabriel, S.; Jacob, J. Coastal morphology along the Central Algarve rocky coast: Driver mechanisms. J. Coast. Res. 2011, SI61, 790-794.

18. Nicod, J. Les Karsts sous couverture (sableuse, argileuse, et/ou détritique) en France, d' après des trabaux récents. Cuad. De Sección. Hist. 1992, 20, 165-185.

19. Cáceres, L.M.; Rodriguez Vidal, J.; Rodriguez Ramírez, A.; Cantano, M. Procesos karsticos en Ia formaci6n Calcarenita de Niebla (Huelva). Geogaceta 1997, 21, 43-46.

20. Marsico, A.; Selleri, G. The solution pipes. In Puglia 2003-Final Conference Quaternary Coastal Morphology and Sea Level Changes; IGCP 437 Project; Mastronuzzi, G., Sanso, P., Eds.; Elsevier: Amsterdam, The Netherlands, 2003; pp. 113-115. 
21. Cabero, A.; Lario, J.; Zazo, C.; Goy, J.L.; Dabrio, C.J.; Borja, F.; Roquero, E.; Silva, P.G.; García-Blázquez, A.; Bardají, T.; et al. Geomorphologic setting and 1755? Tsunami deposits at Cape Trafalgar. In Palaeoseismicity and Active Tectonics during the Quaternary in the Gibraltar Strait (Betic Cordillera, South Spain); IGME: Madrid, Spain, 2009; pp. 74-84.

22. De Waele, J.; Mucedda, M.; Montanaro, L. Morphology and origin of coastal karst landforms in Miocene and Quaternary carbonate rocks along the central-western coast of Sardinia (Italy). Geomorphology 2009, 106, 26-34. [CrossRef]

23. De Paor, D.; Whitmeyer, S.J. Geological and geophysical modelling on virtual globes using KML, COLLADA and Javascript. Comput. Geosci. 2011, 37, 100-110. [CrossRef]

24. De Miguel, D.; Brilha, J.; Alegret, L.; Arenillas, I.; José, A.A.; Gilabert, V.; Strani, F.; Valenciano, A.; Villas, E.; Azanza, B. Linking geological heritage and geoethics with a particular emphasis on palaeontological heritage: The new concept of 'palaeontoethics'. Geoheritage 2021, 13, 69. [CrossRef]

25. García Cortés, A.; Carcavilla, L.; Díaz-Martínez, E.; Vegas, J. Documento Metodológico para la Elaboración del Inventario Español de Lugares de Interés Geológico (IELIG); Instituto Geológico y Minero de España: Madrid, Spain, 2018; 61p.

26. Martínez-Graña, A.; Goy, J.; Cimarra, C. Virtual tour of geological heritage: Valourising geodiversity using Google Earth and QR code. Comput. Geosci. 2013, 61, 83-93. [CrossRef]

27. Kroeger, K.F.; Reuter, M.; Forst, M.H.; Breisig, S.; Hartmann, G.; Brachert, T.C. Eustasy and sea water Sr composition: Application to highresolution Sr-isotope stratigraphy of Miocene shallow-water carbonates. Sedimentology 2007, 54, 565-585. [CrossRef]

28. Martínez-Graña, A.M.; Bajo, I.; González-Delgado, J.A.; Cárdenas-Carretero, J.; Abad, M.; Legoinha, P. Virtual geo-resources applied to the palaeontological heritage in Sevilla (Guadalquivir Neogene basin, Spain). Geoheritage 2018, 10, 473-482. [CrossRef]

29. Martínez-Graña, A.; Goy, J.L.; González-Delgado, J.A.; Cruz, R.; Sanz, J.; Bustamante, I. 3D Virtual itinerary in the Geological Heritage from Natural Parks in Salamanca-Ávila-Cáceres, Spain. Sustainability 2019, 11, 144. [CrossRef]

30. González-Delgado, J.A.; Andrés, I.; Sierro, F.J. Late Neogene Molluscan faunas from NE Atlantic (Portugal, Spain, Morocco). Geobios 1995, 28, 459-471. [CrossRef]

31. Civis, J.; Pais, J.; González-Delgado, J.A.; Legoinha, P. Síntesis paleontológica del Tortoniense Superior de Cacela (Algarve, Portugal). Resumos das XVI Jornadas de la Sociedad Española de Paleontología/I Congresso Ibérico de Paleontologia; Universidade de Évora: Évora, Portugal, 2000; pp. 10-11.

32. Santos, A. Tafonomia e Paleoicnologia do Neogénico Superior do Sector Cacela-Huelva (SE da Ibéria), University of the Algarve: Faro, Portugal, 2005; 207p, Unpublished Work.

33. Santos, A.; Mayoral, E. Bioerosion versus colonization on Bivalvia: A case study from the Upper Miocene of Cacela (SE Portugal). Geobios 2008, 41, 43-59. [CrossRef]

34. Martínez-Graña, A.M.; Legoinha, P.; González-Delgado, J.A.; Dabrio, C.J.; Pais, J.; Goy, J.L.; Zazo, C.; Civis, J.; Armenteros, I.; Alonso-Gavilán, G.; et al. Augmented Reality in a Hiking Tour of the Miocene Geoheritage of the Central Algarver Cliffs (Portugal). Geoheritage 2017, 9, 121-131. [CrossRef]

35. Dabrio, C.J.; González-Delgado, J.A.; Armenteros, I.; Civis, J.; Pais, J.; Alonso-Gavilán, G.; Legoinha, P. Facies changes and paleogeographical implications in the Serravallian of the Lagos-Portimao Formation (Praia da Rocha, S Portugal). Geo-Temas 2008, 10, 131-134.

36. Armenteros, I.; Dabrio, C.J.; Legoinha, P.; González-Delgado, J.A.; Martínez-Graña, A.; Alonso-Gavilán, G.; Civis, J.; Pais, J. Facies and sequence analysis of Miocene open-shelf warm-temperate carbonates in Portimão (Lagos-Portimão Formation, Portugal). Facies 2019, 65, 33. [CrossRef]

37. Da Silva, C.M.; Cachao, M.; Rebelo, A.C.; Johnson, M.E.; Baarli, B.G.; Santos, A.; Mayoral, E. Paleoenvironment and taphonomy of lower Miocene bivalve and macroid assemblages: The Lagos Biocalcarenite (Lagos-Portimao Formation, southern Portugal). Facies 2019, 65, 6. [CrossRef] 